\title{
Impact of climate change on irrigation requirements in terms of groundwater resources
}

\author{
Yu Zhou • François Zwahlen • Yanxin Wang • Yilian Li
}

\begin{abstract}
Climate change affects not only water resources but also water demand for irrigation. A large proportion of the world's agriculture depends on groundwater, especially in arid and semi-arid regions. In several regions, aquifer resources face depletion. Groundwater recharge has been viewed as a by-product of irrigation return flow, and with climate change, aquifer storage of such flow will be vital. A general review, for a broadbased audience, is given of work on global warming and groundwater resources, summarizing the methods used to analyze the climate change scenarios and the influence of these predicted changes on groundwater resources around the world (especially the impact on regional groundwater resources and irrigation requirements). Future challenges of adapting to climate change are also discussed. Such challenges include water-resources depletion, increasing irrigation demand, reduced crop yield, and groundwater salinization. The adaptation to and mitigation of these effects is also reported, including useful information for water-resources managers and the development of sustainable groundwater irrigation methods. Rescheduling irrigation according to the season, coordinating the groundwater resources and irrigation demand, developing more accurate and complete modeling prediction methods, and managing the irrigation facilities in different ways would all be considered, based on the particular cases.
\end{abstract}

Received: 21 December 2009 / Accepted: 14 June 2010

Published online: 1 July 2010

(C) Springer-Verlag 2010

Y. Zhou $\cdot$ Y. Wang $\cdot$ Y. Li

School of Environmental Studies and MOE Key Laboratory of Biogeology and Environmental Geology,

China University of Geosciences,

No. 388 Lumo Road, Wuhan, 430074, China

Y. Zhou ( $) \cdot$ F. Zwahlen

Centre d'Hydrogéologie et de Géothermie (CHYN),

Institut de Géologie et d'Hydrogéologie,

Université de Neuchâtel,

Rue Emile-Argand 11, Case Postal 158, Neuchâtel, Switzerland

e-mail: yu.zhou@unine.ch

Tel.: +41-76-2300323

Fax: $+41-32-7182603$
Keywords Climate change - Groundwater management . Irrigation $\cdot$ Arid regions $\cdot$ Salinization

\section{Introduction}

The Third Assessment Report of the Intergovernmental Panel on Climate Change (IPCC 2001) has stated that emissions of greenhouse gases or aerosols due to human activities will raise global temperatures causing what is well known as 'global warming'. As documented in the 2007 reports of the IPCC (IPCC 2007), substantial advances have been made in scientific understanding of human-caused climate change, the risks it poses to people and ecological systems, and response options to mitigate and adapt. Potential consequences of an elevated atmospheric $\mathrm{CO}_{2}$ concentration are not only higher mean temperatures (likely to affect minimum winter temperature, summer average temperature, and rainfall amounts and intensities during the growing season (Baron et al. 1998, 2000), but also changes in the temporal and spatial distribution of precipitation, accompanied by an increased risk of both heavy rainfall events and droughts. Since the capacity of the atmosphere to hold water increases exponentially with its temperature, evaporation and transpiration rates will increase. Temperature changes are also expected to affect crop communities by changing the length of the growing season (Alward et al. 1999). Other relevant climate variables such as cloudiness, humidity and windiness are also likely to be linked to the changes in temperature (Gleick 1987; Komuscu et al. 1998).

If global warming occurs as projected, global temperatures will continue to rise between 1.4 and $5.8^{\circ} \mathrm{C}$ by 2100 due to the emissions of greenhouse gases (McCarthy et al. 2001). The change of temperature and rainfall patterns will directly deplete soil moisture which can greatly reduce agricultural yield (Rosenzweig and Hillel 1998; Ojima et al. 1999) and also causes more demand for irrigation. The effects will be felt directly, in the case of rain-fed agriculture, and indirectly, in the case of watershed hydrology and runoff and, therefore, irrigated agriculture. As competition between urban development and agriculture increases in some regions, issues pertaining to water resources are likely to become even more contentious because new water is limited and expanding cropped area will claim what is available, and more. The pattern of food demand will also change, since 
higher value secondary products such as meat, dairy products, and eggs require more water than cereals used for direct consumption (Van Hofwegen and Svendsen 2000). China provides a compelling indicator of trends in crop production patterns in recent decades (Fig. 1). As another example, Syria's local agricultural policy of subsidized inputs and supported prices for the expansion of cotton, wheat, maize and beat root areas, is leading to more demand for groundwater irrigation and causing economic stress (Gül et al. 2005).

As a result of global warming, surface temperatures should rise around the world, but not uniformly in all regions. Although there will be more precipitation overall, not all regions will receive more; some will almost certainly receive less. The expected impacts of climate change may further stress water resources by widening the gap between the demand for, and supply of, water for irrigation. For crop production, the predicted increases in atmospheric $\mathrm{CO}_{2}$ concentration imply higher productivity (Downing et al. 2003). However, the effect could be counteracted by higher temperatures and lower rainfall. Higher temperatures are likely to increase crop water requirements and more irrigation water will be needed per irrigated hectare. Irrigation water requirements vary according to the balance between precipitation and evapotranspiration and the resultant fluctuations in soil-moisture status.

The water-use sector that will be influenced most by climate change is irrigation. In 1997, irrigation was the largest use sector, and about $67 \%$ of the current global water withdrawal and $87 \%$ of the consumptive water use (withdrawal minus return flow) was for irrigation purposes (Shiklomanov 1997). Untill 2006, the irrigated area had expanded to over 2.70 million $\mathrm{km}^{2}$ worldwide, about $18 \%$ of total cultivated land. Irrigation water withdrawals are $70 \%$ of the total anthropogenic use of renewable water resources - about $2,630 \mathrm{~km}^{3} /$ year out of $3,815 \mathrm{~km}^{3} /$ year (Fischer et al. 2007). Irrigated agricultural land comprises less than one fifth of the total cropped area but produces about two fifths of the world's food. It is generally expected that irrigated agriculture will have to be extended

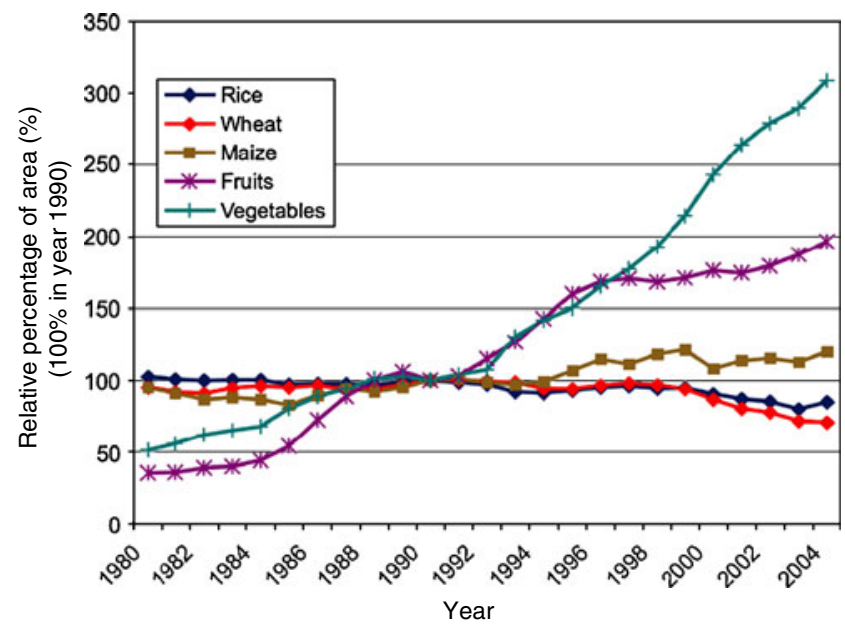

Fig. 1 Evolution of harvested area for major crops in China, 1980-2004 (Turral et al. 2009, with permission from Elsevier) in the future in order to feed the world's growing population. However, it is not yet known whether there will be enough water available for the necessary extension. Arid and semi-arid climatic conditions prevail on about 12 and $14 \%$ of the earth's surface, respectively. In those regions, unlike the areas where shallow water tables support a greater density of vegetation, additional water for plant growth and transpiration is needed. Profitable agriculture in these areas is feasible only with irrigation. For example, in Syria, a water-scarce area, groundwater is estimated to constitute more than $50 \%$ of the total volume of irrigation water (JICA 1997; Jumaa et al. 1999); approximately $21 \%$ of the cultivated land is irrigated, $60 \%$ with groundwater and $40 \%$ with surface water (SMAAR 1999). Although Syria's annual per capita water availability is less than $1,000 \mathrm{~m}^{3}, 90 \%$ of Syria's current water withdrawal is used for irrigation (Wakil 1993).

Compared with surface-water resources, there has been less research into the impacts of climate change on irrigation requirements in terms of groundwater resources and also linkages within the hydrological cycle. This paper addresses three facets of climate-change severity of the climate-change scenario, the influence of climate change on groundwater resources and irrigation requirement, and the existing or potential environmental problems and adaptation measures.

\section{Methods to analyze climate change}

\section{Climate-change scenarios}

Climate-change scenarios are coherent, internally consistent and plausible images of possible future climate that can be used as tools to analyze how possible future changes may affect the environment and the social, economic or institutional fabric of society. Predicting the future accurately is difficult, particularly when the outcome or the predictions themselves can generate feedback and changes in human behavior. Therefore, assessments of the potential impacts of climate change on water-resources use scenarios of possible future changes, which hopefully encompass much of the range of likely futures. These scenarios provide a convenient and appropriate tool for analyzing how different driving forces and responses might influence future outcomes, and to assess the associated uncertainties. New scenarios published in the Intergovernmental Panel of Climate Change (IPCC) Third Assessment Special Report on Emission Scenarios (IPCC-TGCIA 1999) have been used widely to analyze possible climate change, its impacts, and mitigation strategies. These are termed the SRES scenarios. For each scenario, climate change projections have been developed to describe predicted consequences in terms of population, carbon dioxide concentration, global mean annual temperature and mean sea level rise (Table 1) (IPCC-TGCIA 1999).

\section{Representation of climate-change impact on groundwater}

Like most complex adaptive systems, climate is metastable, exhibiting aspects of both regular and chaotic behavior. Over 
Table 1 Summary of the Special Report on Emission Scenarios (SRES) and their estimated environmental consequences

\begin{tabular}{|c|c|c|c|c|c|}
\hline Scenario estimates & $\begin{array}{l}\text { SRES scenarios for } 2100 \\
1990\end{array}$ & A1 & $\mathrm{A} 2$ & B1 & B2 \\
\hline World population (billion) & 5.252 & 7.1 & 15.1 & 7.2 & 10.4 \\
\hline $\mathrm{CO}_{2}$ concentration (parts per million) $)^{\mathrm{a}}$ & 354 & 680 & 834 & 547 & 601 \\
\hline Global annual mean temperature increase $\left({ }^{\circ} \mathrm{C}\right)^{\mathrm{b}}$ & - & 2.52 & 3.09 & 2.04 & 2.16 \\
\hline Estimated range in global temperature rises $\left({ }^{\circ} \mathrm{C}\right)^{\mathrm{C}}$ & - & $1.7-3.66$ & $2.12-4.41$ & $1.37-2.99$ & $1.45-3.14$ \\
\hline Global mean sea-level rise $(\mathrm{cm})^{\mathrm{b}}$ & _ & 58 & 62 & 50 & 52 \\
\hline Estimated range in sea-level rise $(\mathrm{cm})^{\mathrm{c}}$ & _ & $23-101$ & $27-107$ & $19-90$ & $20-93$ \\
\hline
\end{tabular}

Scenario definitions: $A 1$ a future world of very rapid economic growth, relatively low population growth and rapid introduction of new and more efficient technology; $A 2$ a differentiated world. The underlying theme is that of strengthening regional and cultural identities, with an emphasis on family values and local traditions, high population growth, and less concern for rapid economic development; $B 1$ a convergent world with rapid change in economic structures, dematerialization and introduction of clean technologies. The emphasis is on global solutions to environmental and social sustainability, including concerted efforts for rapid technology development, dematerialization of the economy, and improving equity; $B 2$ a world in which emphasis is on local solutions to economic, social and environmental sustainability. It is a heterogeneous world with less rapid, and more diverse technological change but a strong emphasis on community initiative and social innovation to find local, rather than global solutions. Changes are with respect to the 1960-1991 baseline; aerosol effects are included IPCC-TGCIA (1999)

${ }^{a}$ Best guess assumptions for the global carbon cycle

${ }^{\mathrm{b}}$ Assuming $2.5^{\circ} \mathrm{C}$ climate sensitivity (climate sensitivity is defined as the equilibrium change in global mean temperature for a doubling in atmospheric $\mathrm{CO}_{2}$ concentration)

${ }^{\mathrm{c}}$ Based on 1.5 and $4.5^{\circ} \mathrm{C}$ climate sensitivity range

the last decade, the representation of regular climatic behavior has been improved (IPCC 1996) through better physics and higher resolution within global climate models (GCMs), leading to better simulations of chaotic behavior such as short-term climate variability and the manifestation of El Niño-like behavior (Knutson et al. 1997, Wilson and Hunt 1997, Timmermann et al. 1999). Generally, there are two broad approaches to examining the impact of climate change on water systems, and their groundwater components: (1) use GCM results to develop a set of scenarios covering likely combinations of changes in rainfall amounts and patterns, coupled to changes in water demand from agriculture or other competing uses (Eckhardt and Ulbrich 2003); or (2) develop more detailed and explicit models derived from regional climate model (RCM) scenarios that predict hydrological impacts across a well defined region, such as a river basin or an aquifer, and which develop spatial and temporal variability in hydrology (Brouyère et al. 2004, Chen et al. 2004). The use of a particular model depends on the quantity and quality of information available. In general, more complete models may be appropriate for research studies, but simpler applications are better for a greater number of investigations as they provide a fast straightforward initial approach to the problems.

Despite advances in these approaches, the uncertainty within climate scenarios still flows through to the prediction of impacts. There is no consensus amongst climate modelers about how close modeling is to reaching a threshold of uncertainty, how far current estimates of uncertainty can be reduced, and what time scale may be required for this to be achieved (Mahlman 1997). The realism of climate models has been tested against a series of observational data (spatial and temporal distribution of temperature, humidity, rainfall, pressure and winds) which provide a major source of confidence in the use of models for climate projection; the ability of a model to simulate interactions in the climate system depends on the level of understanding of the geophysical and biochemical processes that govern the climate system (CSIRO 2007).

Altered precipitation patterns will modify groundwater recharge, with some areas receiving increased recharge and others suffering reductions. To refine our understanding of the extent and magnitude of climate change and better manage groundwater resources, the vulnerability of groundwater resources to drought, over-abstraction and quality deterioration must be assessed in the context of climate change; regional water budgets need to be quantified so that temporal and spatial distribution of water availability can be better understood. These budgets need to address all components of the water cycle, including water content in the atmosphere, soil and vegetative cover. The interaction between these components needs to be linked to information about current and future climate regimes and made available to land and water managers.

Estimating groundwater recharge is a complex problem affected by many factors, not just meteorological but also the type of ground, vegetation and physiographic characteristics and other geological properties (Lee et al. 2006; Scibek and Allen 2006). Assessing the links between the observed decline in groundwater levels and historical drought, changes in irrigation and groundwater withdrawals requires simultaneous consideration of the variation of these factors in space and time together with the properties of the aquifers. Numerical groundwater-flow modeling is currently the most comprehensive method available for studying the complex, interrelated factors governing groundwater systems. Stresses such as drought and changes in groundwater withdrawals or irrigation can be simulated, and simulated groundwater levels can be used to predict how groundwater levels in the real aquifer will be affected. Long-term trends in climate will possibly affect groundwater recharge, water levels, and availability of groundwater in the future. Still, previous researchers have adopted numerical modeling based on observed data 
and made some reasonable predictions, which are summarized in the following.

\section{Influence of climate change on groundwater resources and irrigation requirements}

Hydro-environmental limits are being challenged through continued withdrawals from watercourses, lakes and aquifers in key grain-producing areas such as the Mediterranean basin, the Punjab, peninsular India and the North China Plain; non-renewable groundwater in these regions is depleted as a result of groundwater withdrawals for agriculture (FAO 2010). In addition, the return flows of degraded water from agriculture lead to salinization, eutrophication and the accumulation of pollutants.

Selected country-level data, collected sometime during the period 1990-1997, are shown in Table 2; groundwater overall represents about $30 \%$ of the total irrigation supply. Although these extracted data are of somewhat variable quality and questionable accuracy and also do not distinguish supplementary from near-continuous irrigation, nor identify conjunctive use of groundwater and surface water, it can be seen that for all these selected countries (Fig. 2), the agricultural groundwater use has more or less intensified. Climate change will act as a force multiplier in this context. It will enhance groundwater's criticality for drought-proofing agriculture and simultaneously multiply the threat to the resource. The technology of water-managed agriculture has also undergone profound changes over the past few decades in some countries. For instance, in India, groundwater supplies directly ca. $80 \%$ of domestic water supply in rural areas, with some 2.8-3.0 million handpump-operated boreholes having been constructed over the past 30 years (Nigam et al. 1998). Some $244 \mathrm{~km}^{3} /$ year groundwater-derived supply was estimated in 2000 by Burke and Moench (2000), being pumped for irrigation from ca. 15-17 million dugwells and tubewells equipped with motorized pumps, with as much as $70 \%$ of national agricultural production being supported by groundwater. Noticeably, Fig. 2 reveals that India was a relatively minor user of groundwater in agriculture in the past compared to countries like the United States and Spain; by 2000, India

Table 2 Groundwater-use data, collected sometime during the period 1990-1997, for agricultural irrigation in selected nations. Source: (Foster and Chilton 2003, with permission from Royal Society Publishing)

\begin{tabular}{llll}
\hline Country & $\begin{array}{l}\text { Irrigated } \\
\text { area }\left(\mathrm{km}^{2}\right)\end{array}$ & $\begin{array}{l}\text { Irrigation use } \\
\left(\mathrm{km}^{3} / \text { year }\right)\end{array}$ & $\begin{array}{l}\text { Proportion of } \\
\text { groundwater }(\%)\end{array}$ \\
\hline India & 501,000 & 460 & 53 \\
China & 480,000 & 408 & 18 \\
Pakistan & 143,000 & 151 & 34 \\
Iran & 73,000 & 64 & 50 \\
Mexico & 54,000 & 61 & 27 \\
Bangladesh & 38,000 & 13 & 69 \\
Argentina & 16,000 & 19 & 25 \\
Morocco & 11,000 & 10 & 31 \\
\hline
\end{tabular}

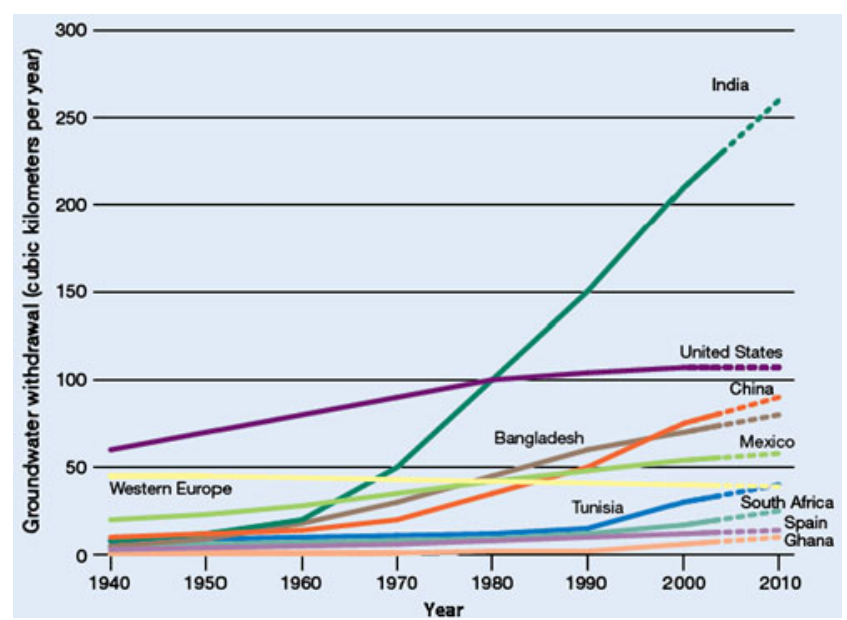

Fig. 2 Growth in agricultural groundwater use in selected countries: 1940-2010. Source: Shah et al. (2007), with permission from IWMI publisher)

had emerged as the global champion in groundwater irrigation, pumping around $220-230$ billion $\mathrm{m}^{3} /$ year, over twice the amount the US did. In India, groundwater has become at once critical and threatened (Shah 2009).

Globally there are important examples of major aquifer depletion as a result of groundwater abstraction for agricultural irrigation, with lowering of the water table over extensive areas. It has been estimated that exploitation of groundwater reserves is currently occurring at a rate of some $10 \mathrm{~km}^{3} /$ year in the North China Plain within the Hai He basin (Foster and Chilton 2003). The major consumptive use of groundwater on the North China Plain is the irrigation for cereal crops. The shallow aquifer has experienced water-table decline of more than $15 \mathrm{~m}$ in the past 30 years over most of the rural areas of the North China piedmont plain, and stretching onto the alluvial flood plain. A nationwide survey in India during 1991, based on survey units of $400-500 \mathrm{~km}^{2}$, revealed a significant decline in the water table, especially in the more arid western and southern states underlain by weathered bedrock aquifers (Burke and Moench 2000). In eastern Indian states (such as Orissa and West Bengal) and in Bangladesh, there is no conclusive evidence of extensive long-term depression of the water table, but competition between deep high-yielding agricultural boreholes and shallow hand-pump domestic wells is a widespread problem (Foster and Chilton 2003). Simulation models have shown that changes in temperature and rainfall influence growth rates and leaf size of the plants that affect groundwater recharge (Kundzewicz and Doll 2007). The trend varies regionally: in some areas, the vegetation response to climate change would cause the average recharge to decrease, but in other areas, recharge to groundwater would more than double. Changing stream flows in response to changing mean precipitation and its variability, rising sea levels and changing temperatures will all influence natural recharge rates (Kundzewicz and Doll 2007). 


\section{Prediction of irrigation demand and groundwater withdrawal}

Global warming and the greenhouse effect will have an impact on the yield of crops. The arid and semi-arid regions are set to suffer further water shortages, while some tropical and temperate areas and boreal Asia are likely to experience increased flooding. Previous researchers, e.g. Tubiello et al. (2000) and Droogers (2004), have investigated the impacts of climate change on irrigation water requirements at specific locations, either using the results of climate-change models directly or applying them to local climate datasets. However, the underlying climate and the climate changes are both spatially varied and the impacts also will be spatially varied. Döll (2002) studied how long-term average irrigation requirements might change around the world under the climatic conditions of the 2020s and the 2070s using datasets from two climate models (ECHAM4 and HadCM3), and related these changes to variations in irrigation requirements. Döll concluded that two thirds of the global area equipped for irrigation in 1995 will possibly suffer from increased water requirements; the negative impact that climate change is likely to have in many regions of the globe, through increased per-hectare irrigation requirements, may be yet another factor that limits irrigation. Thomas (2008) modeled the effects of climate change on irrigation requirements for crop production in China; regional cropping calendars and the modeling results show that during the period 1951-1990, irrigation demand displayed a considerable variation both in temporal and spatial respects, and the future scenarios indicate a varied pattern of generally increasing irrigation demand and an enlargement of the subtropical cropping zone, which is not the same as poleward migration of cropping zones that is anticipated by the US Department of Agriculture (USDA 2008).

A general methodology proposed by Bouraoui et al. (1999) disaggregated outputs of large-scale models and made information directly usable by hydrologic models, which was then applied to a $\mathrm{CO}_{2}$-doubling scenario in the Bièvre-Valloire (France) watershed through the development of a local weather generator. Despite its possible uncertainties, the results illustrate that the doubling of atmospheric $\mathrm{CO}_{2}$ would probably have negative impacts on groundwater resources. First, there would be a decrease of drainage below the root zone of plants; second, there would be an increase in the soil-water deficit in the root zone, followed by larger groundwater withdrawal for irrigation.

Loaiciga et al. (2000) assess climate-change impacts in a regional karst aquifer using diverse historical time seriesextreme shortage, near average and above average recharge - scaled for double- $\mathrm{CO}_{2}$ conditions. Climate scenarios generated with one GCM (GFDL R30) were used to simulate aquifer impacts with different pumping rates and then the results were compared to a lumped parameter groundwater model run with climate-forcing data from six other GCMs and using historical pumping rates. The study concludes by proposing reduced pumping rates for the future to minimize impacts on spring discharge and groundwater levels under double- $\mathrm{CO}_{2}$ climate conditions.
Recent statistical analyses regarding Hawaii indicate that groundwater discharge to streams has decreased from 1913 to 2002; the decrease is coincident with a downward trend in rainfall, and may indicate a long-term decline in groundwater storage and recharge (Oki 2004). Aguilera and Murillo (2009) used a purpose-designed mathematical model, termed estimation of recharge in over-exploited aquifers (ERAS). They applied this to four over-exploited karstic aquifers in Alto Vinalopó (Alicante, Spain), with the goal of generating a synthesized series of values for natural groundwater recharge for the 100 years of the twentieth century. Results show that there was a notably rapid decrease in the mean annual groundwater recharge during the first three decades of the century. In the four aquifers, the mean annual groundwater recharge fell by over 50\% between 1900-1910 and 1990-2000. If the same trend continues, the hypothetical evolution of the mean annual groundwater recharge will continue a logarithmically decreasing trend. Hiscock et al. (2008) estimated decreases in annual potential groundwater recharge for southern Spain of around $78 \%$ for the 21 st century. Priyantha Ranjan et al. (2006) found that in arid areas in Sri Lanka, evapotranspiration and not precipitation is the leading factor in determining groundwater recharge and that, in this sense, agricultural lands have less evapotranspiration and provide higher groundwater recharge. Eckhardt and Ulbrich (2003) observed important effects on intra-annual groundwater recharge (summer decreases over $50 \%$ ) in a small catchment in Germany, partially due to physiological plant responses to increased atmospheric $\mathrm{CO}_{2}$ levels which reduce stomatal conductance and thus counteract increasing potential evapotranspiration induced by temperature rise and decreasing rainfall. Scibek and Allen (2006) found small impacts of climate changes on two small, unconfined, highly permeable aquifers in North America; at the site in which river-aquifer interactions occur, water levels within the floodplain respond significantly and more directly to shifts in the river hydrograph under scenarios of climate change. At those latitudes, groundwater recharge may even increase, as observed by Jirkama and Sykes (2007) for a river watershed in Ontario (Canada).

A further, more detailed case study presented by Hiscock and Tanaka (2006) uses a numerical groundwater model to investigate the possible impacts of climate change on saline intrusion in a low-lying coastal area in East Anglia, UK. In this example, compared to the 1970s baseline condition, a rise in sea level in the 2080s by $57 \mathrm{~cm}$ and a $60 \%$ decrease in annual actual groundwater recharge under a medium-high gas-emissions scenario will potentially cause saline water to advance $1,700 \mathrm{~m}$ further inland into the coastal sand and gravel aquifer. As a consequence of the shallow depth of saline water in the coastal aquifer, the chloride concentration in coastal drains may increase to about $4,000 \mathrm{mg} / \mathrm{L}$ in the $2080 \mathrm{~s}$.

Hsu et al. (2007) adopted a numerical modeling approach based on a hydrogeological model which comprises information on lithology, hydraulic conductivity, electrical conductivity, and tritium and oxygen isotopes, to investigate the response of the groundwater system to climate variability at Pingtung Plain, Taiwan. Applying the 
model to the next two decades, the outputs show that, under the stress of climate change, groundwater levels in the wet season of 2022 will be more than $3 \mathrm{~m}$ lower than those at present in the proximal fan; in the northern part of the Pingtung Plain, the groundwater difference can be up to $10 \mathrm{~m}$; and in the coastal area, the groundwater level decreases range from 0 to $6 \mathrm{~m}$. Suitable strategies for water-resource management in Taiwan in response to future climatic change are imperative.

Priyantha Ranjan et al. (2006) introduced a model elaborating on the changes in fresh groundwater loss with respect to climate change, land-use pattern and hydrologic soil condition, based on the sharp interface assumption illustrated in Fig. 3. When the aquifer is totally filled with freshwater (interface 1), the freshwater loss can be considered as zero and the movement of the salinity interface landward (interface 2) leads to a decrease in the amount of freshwater in the aquifer. When the salinity interface coincides with the piezometric head, that is, the whole aquifer fills with saltwater, and if the groundwater recharge is zero, the freshwater loss will be $100 \%$. Priyantha Ranjan also adopted the aridity index to represent the variations in precipitation and temperature. The interesting finding is that deforestation leads to increased groundwater recharge in arid areas, because deforestation leads to reduced evapotranspiration although it favors runoff. The combined effects of deforestation and aridity index on fresh groundwater loss show that deforestation causes an increase in the recharge and existing fresh groundwater resource in arid climates. This is proved by the examples in West Africa, in which the impacts of land clearance overrode the effects of prolonged droughts, resulting in a $~ 2.5$ fold increase of the drainage density and a 4-m rise in groundwater levels in the second part of the twentieth century (Leblanc et al. 2008; Favreau et al. 2009). However, this does not necessarily imply deforestation should be encouraged, because of the role forests play in stabilizing the global climate.

From Brouyère's et al. (2004) modeling application on the chalky aquifer of Geer basin in Belgium, it appears that the evaluation of the impact of climate change on groundwater reserves and on base flow is not straightforward. On a pluri-annual basis, most tested scenarios predict a decrease in groundwater levels and reserves in relation to variations in climatic conditions. However, the tested scenarios do not show enhancement of the seasonal variations in groundwater levels; in other words, regardless of the characteristics of

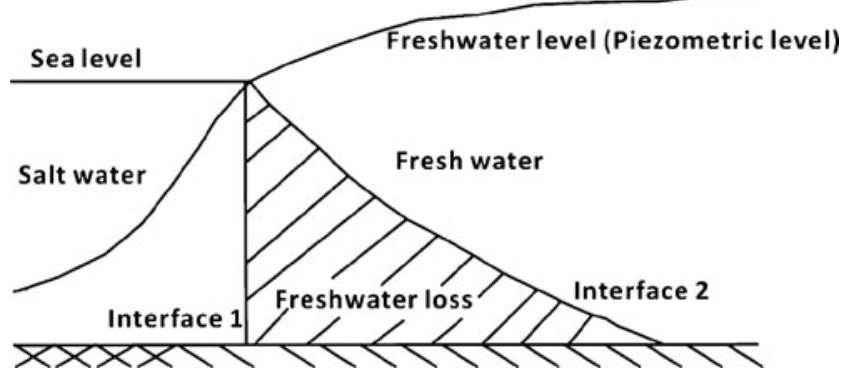

Fig. 3 Loss of fresh groundwater resource due to salinization. Source: Priyantha Ranjan et al. (2006, with permission from Elsevier) weather conditions (wet or dry years), the percolation to the aquifer will be reduced compared to present recharge conditions.

Another climate-change-sensitivity analysis was completed by Allen et al. (2004) for the Grand Forks aquifer in south-central British Columbia, Canada; the current climate data of the region were modified to account for the projected changes in air temperature and precipitation, and to calculate different recharge, which was then applied to a calibrated three-dimensional groundwater-flow model to establish a base-case model for the sensitivity analysis. High-recharge and low-recharge simulations of Allen et al. (2004) resulted in approximately a $+0.05 \mathrm{~m}$ increase and $\mathrm{a}-0.025 \mathrm{~m}$ decrease, respectively, in water-table elevations throughout the aquifer. Simulated changes in river-stage elevation, to reflect higherthan-peak flow levels (by 20 and 50\%), resulted in average changes in the water-table elevation of 2.72 and $3.45 \mathrm{~m}$, respectively. Lower-than-base flow levels (by 20 and 50\%) resulted in average changes of -0.48 and $-2.10 \mathrm{~m}$, respectively. Another study in this area of Canada by Scibek et al. (2007), from the perspective of groundwater/surface-water interaction, used downscaled Canadian Coupled Global Model 1 (CGCM1) downscaling to predict basin-scale runoff for the Kettle River upstream of Grand Forks; the results showed that future climate scenarios indicate temporal shifts in river hydrographs. Modeled water-level differences are less than $0.5 \mathrm{~m}$ away from floodplain, but can be greater than $0.5 \mathrm{~m}$ near the river. The shift for the 2040-2069 climate is larger than for the 2010-2039 climate, although the overall shape of the hydrograph remains the same. The maximum groundwater levels associated with the peak hydrograph are very similar to present climate because the peak discharge is not predicted to change, only the timing of the peak. A small increase of water levels due to an increase in recharge is forecast for future climate scenarios, but these increases tend to occur only in areas that are not strongly influenced by the river, which is inconsistent with Allen's earlier simulation results.

Future regional and global irrigation water requirements were computed by Fischer et al. (2007) as a function of both projected irrigated land and climate change; simulations were performed from 1990 to 2080 and impacts of climate change on world aggregate net-irrigation water requirements are significant. In those simulations, the higher temperatures and altered precipitation regimes impacted net-irrigation water requirements in two distinct ways: by affecting crop evapotranspiration rates and, thus, crop water demand, and by altering crop calendars. By 2080, an additional 395-410 billion $\mathrm{m}^{3}$ of water, in terms of net water requirements, corresponds to an additional $670-725$ billion $\mathrm{m}^{3}$ in agricultural water withdrawals for irrigation. These figures mean an increase of about $+20 \%$ in global irrigation water needs by 2080 . Some important regional dynamics were also computed. Two thirds of the increase (75-80\% in developing countries, but only $50-60 \%$ in developed countries) results from an increase in daily water requirements, and one third occurs because of extended crop calendars in temperate and subtropical zones. Fischer et al. (2007) also indicated that after 2050, temperature increases are likely to be strong 
enough to increase water deficits and, thus, irrigation requirements of crops, regardless of changes in precipitation patterns.

\section{Impact of irrigation source on groundwater and adaption strategies}

In irrigated semi-arid and arid regions, accurate knowledge of groundwater recharge is important for the sustainable management of scarce water resources, since irrigation simultaneously removes water from focused recharge sources while creating new sources of diffuse recharge. In irrigated regions, accurate knowledge of recharge, evaporation, and transpiration is especially important for the sustainable management of scarce water resources (e.g., Gartuza-Payán et al. 1998). Jiménez-Martínez et al. (2009) estimated irrigation return flow in the Campo de Cartagena area of southeast Spain, a semi-arid region where irrigation return flow accounts for a substantial portion of recharge, and the fraction of applied water (irrigation plus precipitation) going to recharge ranged from $22 \%$ for a summer melon crop to $68 \%$ for a fall lettuce crop. Izuka (2006) have reported the groundwater model simulations of the Kilohana-Puhi well field in the southern Lihue Basin, Kauai, Hawaii, to determine whether the decline in groundwater levels observed in the 1990 s to early 2000 s is related to drought, decreases in sugarcane irrigation, and changes in groundwater withdrawal; the results indicate that the loss of recharge-enhancing furrow-irrigation had a larger effect on the decline in groundwater levels than did either drought or increasing groundwater withdrawal, at least in the KilohanaPuhi wells. Groundwater withdrawal effects are long in duration but small in magnitude relative to the overwhelming effect of irrigation, whereas drought effects are high in magnitude and widespread but of short duration. Irrigation in the future will probably not return to the high levels prevalent during the twentieth century, so the decline in groundwater levels resulting from the reduction and loss of sugarcane irrigation can be considered permanent. The possibility also exists that groundwater withdrawals will increase in the future; whether or not regional groundwater levels will be substantially affected depends on the magnitude and location of the increases.

Water scarcity in arid zones led to the development of means and technologies to adjust the irrigation. It is well known that irrigation and fertilizer application can affect groundwater quality through the leaching of nutrients and through salinization (Chen et al. 2005; Oenema et al. 2005). Between 9 and $25 \%$ of irrigated areas in Tunisia, the United States, India, China and South Africa are salt-affected. In Pakistan, the share is estimated to even surpass $25 \%$ (CISEAU 2006).

Globally, about $1-2 \%$ of irrigated areas becomes unsuitable for agriculture each year, mostly in arid and semi-arid regions (FAO 2002). In semi-arid cases, the degree of nitrate contamination and salinization depends greatly on the irrigation source; surface-water use for irrigation can trigger a groundwater freshening mechanism and thus invert the trend of increasing salinities (Stigter et al. 2006). Freshening occurs, mainly attributed to the end of the groundwater extractions and associated recycling process, the increased groundwater discharge and the additional recharge from return flow. Irrigation return flow can be a little mineralized, but extremely high in nitrate, as was found to occur in a surface-water irrigation district of the Ebro River basin in Spain (Causapé et al. 2004). From the report by Stigter et al. (2006) on Campina da Luz, a semi-arid region in south Portugal, the shift from groundwater to surface-water irrigation for citrus orchards resulted in the reduction of the nitrogen residual in soil and groundwater. The reduced nitrogen load is directly related to the absence of nitrogen in surface water and, thus, there is a much lower risk of overfertilization; before that time fertilizers were applied in excess to crop requirements in that area because the high levels of nitrogen already present in the groundwater were never taken into account. Stigter et al. (2006) also indicated that the shift towards surface water for irrigation influenced the groundwater heads, i.e., a sharp rise of the water table in Campina da Luz; therefore, possibly entering the root zone and damaging the citrus trees at some locations. Nevertheless, climate change will have impact on both groundwater and surface-water resources as source options at the same time. This shifting approach with respect to source options may not be available in the near future because of global climate change and shrinking freshwater resources. Irrigated agriculture could become more vulnerable, due to irrigation water reduction caused by the expected higher withdrawal or in response to climate change and a reduction in precipitation.

Forkutsa et al. (2009) brought up the mitigation strategies for the case of secondary soil salinization in the Khorezm region of Uzbekistan (located in the Aral Sea basin), triggered by years of ill-managed irrigation. In Khorezm, overall soil salinity has only been controlled by pre-season salt leaching using large amounts of water, and Forkutsa et al.'s analysis revealed that reducing soil evaporation by adding a surface residue layer would notably decrease secondary soil salinization; owing to the reduced capillary rise of groundwater, the post-season salt contents of the three studied fields were reduced by $12-19 \%$ compared with residue-free conditions. Even lowering the water table would be improving the efficiency of the drainage system because simulations revealed that lowering the groundwater to below $2-m$ soil depth would reduce the post-season salt content in the $2-\mathrm{m}$ soil profile of the three fields by $36-59 \%$ when compared with unaltered conditions. However, an improved irrigation and drainage systems needs to be implemented in concert with reliable, timely irrigation management, so as to sustain the present production levels while reducing future leaching demands.

Due to water scarcity and uneven water distribution in many regions of the world, irrigation practices are carried out using water with poor chemical and microbiological quality, causing salt accumulation in soil, groundwater contamination and health risks. In recent years, the use of treated, partially treated or raw industrial effluent for irrigating productive agriculture or forest crops has become a popular alternative to discharge into surface-water bodies (Al-Jamal et al. 2002; 
Phukan and Bhattacharyya 2003). Under effluent-irrigation areas, the effluent quality, soil characteristics, depth to water table, quality of the receiving groundwater, and the proximity of the effluent irrigation area to discharging areas (like a river, creek, stream or other water body) determine the extent to which the effluent-irrigation-induced recharge impacts the groundwater (Bond 1998; Dominguez-Mariani et al. 2003). If the groundwater salinity is lower than the receiving surface-water body, the salinity of the receiving body will reduce due to dilution. The level of dilution depends on the rate of recharge, effluent-irrigation area, volume of the receiving body and the rate of groundwater flow (due to aquifer permeability and hydraulic gradient) under the effluent-irrigation areas. Thus, while the addition of salt to underlying groundwater is often inevitable, this impact needs to be weighed up in consideration with all risks and benefits relating to effluent reuse. Khan et al. (2007) present the impact of using treated effluent from a pulp and paper mill on groundwater dynamics at a farm (covering areas both under and outside the effluent-irrigation paddocks), and on the flows in the adjacent creek, using field observation data and computer simulation results. In this process of assessing groundwater dynamics, particular emphasis was given to incorporating the impacts of effluent irrigation under a range of climate and water-availability conditions. Under average climatic conditions, the combined effect of irrigation and rainfall creates a larger hydraulic gradient towards the creek thereby depleting the aquifer storage more, as compared to the effects of wet and dry climatic conditions. Khan et al. (2007) suggested that with better balanced use of surface and groundwater, with the corollary of better management of all water resources, there would be less risk of salinization due to evaporation from shallow water tables.

Yang et al. (2002) analyzed the response of groundwater to rainfall by using data on groundwater levels in Gaocheng City in the alluvial plain of the Taihang Mountain in north China for 1974-1998, and found that an increase in irrigation resulting from the decrease of precipitation by $100 \mathrm{~mm}$ could lead to a drawdown of groundwater by a rate of $0.56 \mathrm{~m} / \mathrm{year}$. The reason for drawdown of the water table was mainly due to water being used for winter wheat production and other crops, but another reason for groundwater level decline was the tremendous decline of upstream groundwater recharge. The groundwater level over the whole year strongly correlated with the amount of precipitation. Precipitation did not recharge groundwater directly but affected groundwater levels through a decrease in irrigation water use. Finally, in order to maintain the groundwater balance, agricultural practices have to save about $180 \mathrm{~mm} /$ year of irrigation water from their present level. In Yang et al's later report (Yang et al. 2006), the simulation shows that, by planning irrigation scientifically, such as moderating water deficits or avoiding irrigation at certain periods (e.g., at a relatively low growth phase of the crops), and enforcing irrigation during certain other periods, $76 \mathrm{~mm}$ of evapotranspiration and $99.5 \mathrm{~mm}$ irrigation water can be saved without much reduction in the yield of winter wheat (only $4.5 \%$ reduction). This is sufficient to decrease the drawdown of groundwater by $0.42 \mathrm{~m} /$ year and to improve water-use efficiency from 1.27 to $1.45 \mathrm{~kg} / \mathrm{m}^{3}$. In summary, demand-based irrigation applications using the local meteorological and root zone soil-moisture observations to define the irrigation schedule would present better management practices.

By using climate-change projections from a group of 17 climate models run under four different global climate IPCC scenarios, the study by Serrat-Capdevila et al. (2007) on the semi-arid San Pedro basin in Arizona and Sonora (USA/Mexico), with groundwater extraction in the basin maintained constant and equal to the current level, showed that recharge in the San Pedro basin over the coming century will decrease $17-30 \%$ depending on the IPCC scenario considered. The multimodel average predicts a decrease of about $31 \%$ evapotranspiration for all scenarios, which would represent a reduction of almost a third in the riparian area and significant changes in its ecosystem. The same projections for net stream gain show a reduction of almost $50 \%$, meaning that average annual base flow in 2100 would be half the base flow in 2000 for any given scenario and the effects on the riparian area could be significant. This implies that, if recharge is about to decrease due to decreased precipitation and increased evapotranspiration, local aquifer extractions should also be reduced, in other words, less pumping, more conservation and greater efficiency will be needed.

Compared to surface storage features, aquifers act as a more resilient buffer during dry spells, especially when they have large storage. India has experienced explosive growth in groundwater demand during recent decades while shifting to groundwater irrigation; and the groundwater demand will expand further in the wake of climate change in direct and myriad ways. In order to ensure groundwater resources as regards the condition of heavy dependence on them, in 2001, India's Central Groundwater Board produced a Master Plan for Groundwater Recharge (Government of India 2005). While the Plan had many limitations and flaws, its most striking objective was to stabilize static postmonsoon groundwater levels throughout India at $3 \mathrm{~m}$ below the ground through a national program of groundwater recharge. Pursuing such a bold objective could be India's best feasible response to climatechange mitigation as well as adaptation (Shah 2009).

\section{Suggestions and conclusions}

In a warming climate, water underground where it is shielded from high evaporation and accessible to large numbers of farmers is invaluable, but there needs to be awareness of the potential for water-resource depletion in many cases. Groundwater storage capacity is only an opportunity if there is a coherent strategy for managed aquifer recharge (IWMI 2010). Such a strategy must be proactive and be supported by regional and national policies appropriate to the socioeconomic and hydrogeological context of the region. Many factors will affect groundwater recharge including changed precipitation and temperature regimes, coastal flooding, 
urbanization and surface sealing, woodland creation, and cropping and rotation changes. In terms of the prediction methods, further steps in studying climate-change impacts on groundwater resources should put more consideration into the modeling approach of indirect effects, like changes in land use, irrigation, and groundwater exploitation optimization. The direct impacts of the climate scenarios are generally regionally more important than those of the socio-economic scenarios. However, the latter cause regional changes and locally the impacts can be highly significant, especially where they lead to major land-use changes. It would also be better if more accurate climate-change scenarios become available and downscaling techniques are improved. To study the response of the groundwater system to the stress of climate change, both long-term meteorological data and a reliable hydrogeological model are required. Iterative modeling may be needed to modify the conceptual model, and uncertainties can be reduced when new data are incorporated in the conceptual model (Bredehoeft 2005). Although any firm statements regarding the accuracy of the modeling results cannot be made without further verification and evaluation, the developed methodology nevertheless provides a practical and useful way to generate a physically based evaluation of the impacts of climate change on a groundwater system.

It is advisable to consider a shift of irrigated agriculture to regions where climate change will decrease per-hectare irrigation requirements based on the predictions. However, comprehensive assessments are necessary, which take into account the future water use by the domestic and industrial sectors as well as the future water-resources situation. It means that adaption measures to mitigate climate-change impact on irrigation demand and groundwater resources should be considered from both sides, to develop more sustainable and efficient methods of irrigation and for protecting groundwater resources. The easiest ways, such as decreasing the planting area or irrigation area, are not feasible, because the local population rely on this food supply and the demand for food may possibly become more intense, so saving water or improving the water-use efficiency would be the best choice. Investments in relatively inexpensive technology would be needed to enhance and stabilize groundwater aquifers that offer water supply close to points of use, permitting frequent and flexible just-in-time irrigation of diverse crops (IWMI 2010). To cope with climate change, water managers might implement adaptation strategies mentioned previously to resolve water stress such as: using an integrated mixed-source irrigation system (like using both groundwater and surface water); using treated, partially treated or raw industry effluent for irrigating productive agriculture; and using meteorological and root zone soil-moisture observations to define the irrigation schedule, etc. However, practices such as wastewater reuse may result in increased recharge (quality and quantity) to the groundwater, accumulation of salts in the soil profile, and risk of runoff of these contaminants into surface-water bodies, and also have impact on the concentration of micropollutants (like pharmaceuticals, endocrine disrupting substances and pathogens), so standards for wastewater reuse should be considered first to avoid unnecessary contamination. In view of pathogenic threats, appropriate wastewater treatment is necessary before use and waterquality criteria become easy to monitor.

It is suggested that farmers should consider planting crops earlier or later and use shorter duration varieties, given that less rainfall will occur in some certain periods, or partly change the location of agriculture production according to the spatial variability of precipitation. Meanwhile, such changes in management would not substantially influence crop yield and could thus be accepted relatively easily by the local farmers and policy-makers. In addition, the use of other watersaving techniques such as micro irrigation systems, which have the capability to apply water precisely to crops and also increase crop yields, and mulch cover in growing seasons, should be encouraged in order to help ensure that use of irrigation water enables the sustainability of groundwater resources. To lower the risk of saline intrusion and protect fresh groundwater resources in coastal areas, a possible adaption plan is to maintain the coastal water level at an elevation lower than the inland groundwater level elevation. This would have the benefit of restricting saline intrusion. Artificial aquifer recharge could also be used if only there are enough available and manageable water resources to make it happen.

Despite all the efforts that can contribute to a reduction of climate change, specific measures should be investigated in order to minimize the effect of climate change on groundwater resources - for example, the development of techniques for artificial recharge of aquifers. The existing facilities and management systems for water resources may not be reliable under the stress of climate change. Suitable strategies for water-resource management in response to hydrological impacts of future climatic change are imperative.

Besides the climate-change impact, the global challenge of increasing food production is another driving force to manage sustainable water resources, as exemplified in the case of Pakistan by Ahmad et al. (2007). Ahmad concluded that real water savings can be achieved by: improving the canal water-supply systems to sustain good quality groundwater resources; reducing evaporation on a priority basis in the rice-wheat zone (located in upper parts of Indus Basin (Punjab) where groundwater is fresh and drainage is reused by downstream users); and targeting technologies that reduce accessions to saline groundwater and also minimize evaporation. Whether improved irrigation efficiency means real water savings depends on the hydrologic interactions between the field, the irrigation system and the entire river basin. It is possible that real water savings are much lower than what might be assumed when field-level calculations are extrapolated to broader scales, because of water recycling and the conjunctive use of surface and groundwater in many cropping systems (Humphreys et al. 2005; Tuong et al. 2005).

Otherwise, mitigation strategies aiming to stabilize greenhouse gas concentrations in the atmosphere at levels preventing 'dangerous' anthropogenic interference with the 
climate system, which is not addressed in this paper, can be considered to mitigate the impact of climate change and, thus, the potential environmental problems it may have directly or indirectly imposed. A framework is also needed to link levels of climate change with levels of impacts through the use of risk assessment. Last, but not least, the climate-change impact on agriculture itself should also be considered. The USDA (2008) related agriculture to climatechange impacts and concluded that the life cycle of grain and oilseed crops will likely progress more rapidly with increased $\mathrm{CO}_{2}$ and temperature, but these crops will increasingly begin to experience failure, especially if climate variability increases and precipitation lessens or becomes more variable; the marketable yield of many horticultural crops (tomatoes, onions, fruits) is very likely to be more sensitive to climate change than grain and oilseed crops, and climate change is likely to lead to a northern migration of weeds. Strategies like planning more crops which respond more positively to increasing $\mathrm{CO}_{2}$ and spatially reorganizing the fields could be effective from a different perspective.

In responding to the challenge of managing groundwater resources and to address the expected effects of human activity and climate change on global groundwater resources, UNESCO-IHP (International Hydrological Program) initiated the GRAPHIC (Groundwater Resources Assessment under the Pressures of Humanity and Climate Change) project in 2004 on a global scale. GRAPHIC will promote and advance sustainable groundwater management considering projected climate change and linked human effects (UNESCO 2008). It will promote a comprehensive understanding of groundwater resources, specifically an evaluation of the changes to groundwater composition, storage and groundwater flux (recharge and discharge rates) from various population pressures and climate-change scenarios. The FAO (2010) also supports adaptive strategies and offers to assist member countries in understanding the implications of climate change on water resources and agriculture; it also aims to develop better regional and local projections of impacts in order to plan adaptive strategies, improve water governance and build specific capacity in water management.

\section{References}

Aguilera H, Murillo JM (2009) The effect of possible climate change on natural groundwater recharge based on a simple model: a study of four karstic aquifers in SE Spain. Environ Geol 57:963-974

Ahmad MD, Turral H, Masih I, Giordano M, Masood Z (2007) Water saving technologies: myths and realities revealed in Pakistan's rice-wheat systems. International Water Management Institute, Colombo, Sri Lanka

Allen DM, Mackie DC, Wei M (2004) Groundwater and climate change: a sensitivity analysis for the Grand Forks aquifer, southern British Columbia, Canada. Hydrogeol J 12:270-290

Alward RD, Detling JK, Milchunas DG (1999) Grassland vegetation changes and nocturnal global warming. Science 283:229-231

Al-Jamal MS, Sammis TW, Mexal JG, Picchioni GA, Zachritz WH (2002) A growth-irrigation scheduling model for wastewater use in forest production. Agric Water Manage 56:57-79
Baron JS, Hartman MD, Kittle TGF, Band LE, Ojima DS, Lammers RB (1998) Effects of land cover, water redistribution, and temperature on ecosystem processes in the South Platte Basin. Ecol Appl 8:1037-1051

Baron JS, Hartman MD, Band LE, Lammers RB (2000) Sensitivity of a high elevation rocky mountain watershed to altered climate and CO2. Water Resour Res 36:89-99

Bond WJ (1998) Effluent irrigation: an environmental challenge for soil science. Aust J Soil Res 36:543-555

Bouraoui F, Vachaud G, Li LZX, Le Treut H, Chen T (1999) Evaluation of the impact of climate changes on water storage and groundwater recharge at the watershed scale. Clim Dyn 15:153-161

Bredehoeft J (2005) The conceptualization model problem: surprise. Hydrogeol J 13(1):37-46

Brouyère S, Carabin G, Dassargues A (2004) Climate change impacts on groundwater resources: modelled deficits in a chalky aquifer, Geer basin, Belgium. Hydrogeol J 12:123-134

Burke JJ, Moench MH (2000) Groundwater and society: resources, tensions and opportunities. United Nations Publication ST/ESA/ 205, UN, New York

Causapé J, Quílez D, Aragüés R (2004) Assessment of irrigation and environmental quality at the hydrological basin level II: salt and nitrate loads in irrigation return flows. Agric Water Manage 70:211-228

Chen Z, Grasby SE, Osadetz KG (2004) Relation between climate variability and groundwater levels in the upper carbonate aquifer, southern Manitoba, Canada. J Hydrol 290:43-62

Chen J, Tang C, Sakura Y, Yu J, Fukushima Y (2005) Nitrate pollution from agriculture in different hydrogeological zones of the regional groundwater flow system in the North China Plain. Hydrogeol J 13:481-492

CISEAU (2006) Irrigation induced salinization. Background paper presented at the 'Electronic conference on Salinization: Extent of Salinization and Strategies for Salt-Affected Land Prevention and Rehabilitation' 6 February-6 March 2006. www.dgroups. org/groups/fao/salinization-conf/docs/BackgroundPaper.doc. Cited Sept 2008

CSIRO (2007) Climate change in Australia. CSIRO and Bureau of Meteorology, CSIRO, Canberra, Australia, $137 \mathrm{pp}$

Döll P (2002) Impact of climate change and variability on irrigation requirements: a global perspective. Clim Change 54:269-293

Dominguez-Mariani E, Carrillo-Chavez A, Ortega A, Orozco-Esquivel MT (2003) Wastewater reuse in Valsequillo Agricultural Area, Mexico: environmental impact on groundwater. Water Air Soil Pollut 155:251-267

Downing T, Butterfield B, Edmonds D, Knox JW, Moss S, Piper B, Weatherhead EK (2003) CCDeW: climate change and demand for water revisited. Final research report to DEFRA, Stockholm Environment Institute Oxford Office, Oxford, UK

Droogers P (2004) Adaptation to climate change to enhance food security and preserve environmental quality: example for southern Sri Lanka. Agric Water Manage 66:15-33

Eckhardt K, Ulbrich U (2003) Potential impacts of climate change on groundwater recharge and streamflow in a central European low mountain range. J Hydrol 284:244-252

FAO (2002) The salt of the earth: hazardous for food production. FAO, Rome. http://www.fao.org/worldfoodsummit/english/ newsroom/focus/focus 1.htm. Cited Sept 2008

FAO (2010) Main findings and short- and medium-term recommendations. FAO, Rome. http://www.fao.org/nr/water/news/ clim-change.html. Cited March 2010

Favreau G, Cappelaere B, Massuel S, Leblanc M, Boucher M, Boulain N, Leduc C (2009) Land clearing, climate variability, and water resources increase in semiarid southwest Niger: a review. Water Resour Res 45, W00A16

Fischer G, Tubiello FN, Velthuizen H, Wiberg DA (2007) Climate change impacts on irrigation water requirements: effects of mitigation, 1990-2080. Technol Forecast Soc Change 74:10831107

Forkutsa I, Sommer R, Shirokova YI, Lamers JPA, Kienzler K, Tischbein B, Martius C, Vlek PLG (2009) Modeling irrigated 
cotton with shallow groundwater in the Aral Sea Basin of Uzbekistan: II. Soil Salinity Dynam Irrig Sci 27:319-330

Foster SSD, Chilton PJ (2003) Groundwater: the processes and global significance of aquifer degradation. Phil Trans R Soc Lond B 358:1957-1972. doi:10.1098/rstb.2003.1380

Gartuza-Payán J, Shuttleworth WJ, Encinas D, McNeil DD, Stewart JB, DeBruin H, Watts C (1998) Measurement and modelling evaporation for irrigated crops in northwest Mexico. Hydrol Process 12:1397-1418

Gleick PH (1987) Regional hydrologic consequences of increases in atmospheric CO2 and other trace gases. Clim Change 10:137-161

Government of India (2005) Master plan for artificial recharge to groundwater in India. Central Groundwater Board, Ministry of Water Resources, New Delhi

Gül A, Rida F, Aw-Hassan A, Büyükalaca O (2005) Economic analysis of energy use in groundwater irrigation of dry areas: a case study in Syria. Appl Energ 82:285-299

Hiscock K, Tanaka Y (2006) Potential impacts of climate change on groundwater resources: from the high plains of the U.S. to the flatlands of the U.K. National Hydrology Seminar 2006, Irish National Committees, Dublin, pp 19-25

Hiscock K, Sparkes R, Hodgson A, Martin JL, Taniguchi M (2008) Evaluation of future climate change impacts in Europe on potential groundwater recharge. Geophys Res Abstr, vol 10. http://www. geophysical-research-abstracts.net/volumes.html. Cited June 2010

Hsu K, Wang CH, Chen KC, Chen CT, Ma KW (2007) Climateinduced hydrological impacts on the groundwater system of the Pingtung Plain Taiwan. Hydrogeol J 15:903-913

Humphreys E, Meisner C, Gupta R, Timsina J, Beecher HG, Lu TY, Singh Y, Gill MA, Masih I, Guo ZJ, Thompson JA (2005) Water savings in rice-wheat systems. Plant Prod Sci 8(3):242-258

IPCC (1996) Climate change 1995: the science of climate change. Contribution of Working Group I to the second assessment report of the Intergovernmental Panel on Climate Change. Cambridge University Press, Cambridge, pp 9-49

IPCC (2001) Climate change 2001: the scientific basis. Contribution of Working Group I to the Third Assessment Report of the Intergovernmental Panel on Climate Change, Cambridge University Press, Cambridge

IPCC (2007) Climate change 2007: climate change impacts, adaptation, and vulnerability-summary for policymakers. Contribution of Working Group II to the Fourth Assessment Report of the Intergovernmental Panel on Climate Change, IPCC, Geneva

IPCC-TGCIA (1999) Guidelines on the use of scenario data for climate impact and adaptation assessment, Version 1. Prepared by Carter TR, Hulme M, Lal M, Intergovernmental Panel on Climate Change, Task Group on Scenarios for Climate Impact Assessment, Geneva

IWMI (International Water Management Institute) (2010) Banking on groundwater in times of change. IWMI Water Policy Brief 32, IWMI, Colombo, Sri Lanka, 8 pp. doi:10.3910/2009.203

Izuka SK (2006) Effects of irrigation, drought, and ground-water withdrawals on ground-water levels in the southern Lihue Basin, Kauai, Hawaii. US Geol Surv Sci Invest Rep 20065291, 42 pp

JICA (Japan International Cooperation Agency) (1997) The study on water-resource development in Northern and Central Basins in the Syrian Arab Republic: final report. Nippon Koei, Tokyo

Jiménez-Martínez J, Skaggs TH, van Genuchten MTh, Candela L (2009) A root zone modelling approach to estimating groundwater recharge from irrigated areas. J Hydrol 367:138-149

Jirkama MI, Sykes JF (2007) The impact of climate change on spatially varying groundwater recharge in the Grand River watershed (Ontario). J Hydrol 338:237-250

Jumaa V, Naji M, Pala M (1999) Review paper on optimizing soil water use in Syria. In: Van Dulmkwden N, Pala M, Studer C, Bieldes CL (eds) Proceedings of workshop on efficient soil water use. Soil Water Use Consortium, Niamey, Niger, 26-30 April 1998; Amman, Jordan, 9-11 May 1999

Khan S, Asghar MN, Rana T (2007) Characterizing groundwater dynamics based on impact of pulp and paper mill effluent irrigation and climate variability. Water Air Soil Pollut 185:131-148
Knutson KR, Manabe S, Gu D (1997) Simulated ENSO in a global coupled ocean-atmosphere model: multidecadal amplitude and CO2 sensitivity. J Clim 10:138-161

Komuscu AU, Erkan A, Oz S (1998) Possible impacts of climate change on soil moisture variability in the southeast Anatolian Development Project (GAP) region: an analysis from an agricultural drought perspective. Clim Change 40:519-545

Kundzewicz ZW, Doll P (2007) Will groundwater ease freshwater stress under climate change? Int. Conf. Groundwater and Climate in Africa, Kampala, Uganda, June 2008

Leblanc MJ, Favreau G, Massuel S, Tweed SO, Loireau M, Cappelaere B (2008) Land clearance and hydrological change in the Sahel: SW Niger. Glob Planet Change 61:135-150

Lee CH, Chen WP, Lee RH (2006) Estimation of groundwater recharge using water balance coupled with base-flow-record estimation and stable-base-flow analysis. Environ Geol 51:73-82

Loaiciga HA, Maidment DR, Valdes JB (2000) Climate change impacts in a regional karst aquifer, Texas, USA. J Hydrol 227:173-194

Mahlman JD (1997) Uncertainties in projections of human caused climate warming. Science 278:1416-1417

McCarthy JJ, Canziani OF, Leary NA, Dokken DJ, White KS (2001) Climate change 2001: impacts, adaptation, and vulnerability. Contribution of Working Group II to the Third Assessment Report of the Intergovernmental Panel on Climate Change. Cambridge University Press, Cambridge

Nigam A, Gujia B, Bandyopadhya J et al (1998) Fresh water for India's children and nature. UNICEF-WWF, New Delhi

Oenema O, Van Liere L, Schoumans O (2005) Effects of lowering nitrogen and phosphorus surpluses in agriculture on the quality of groundwater and surface water in The Netherlands. J Hydrol 304:289-301

Ojima D, Garcia L, Elgaali E, Miller K, GF KT, Lackett J (1999) Potential climate change impacts on water resources in the Great Plains. J Am Water Resour Assoc 35:1443-1454

Oki DS (2004) Trends in streamflow characteristics at long-term gaging stations, Hawaii. US Geol Surv Sci Invest Rep 2004$5080,120 \mathrm{pp}$

Phukan S, Bhattacharyya KG (2003) Modification of soil quality near a pulp and paper mill. Water Air Soil Pollut 146:319-333

Priyantha Ranjan S, Kazama S, Sawamoto M (2006) Effects of climate and land use changes on groundwater resources in coastal aquifers. J Environ Manage 80:25-35

Rosenzweig C, Hillel D (1998) Climate change and the global harvest: potential impacts of the greenhouse effect on agriculture. Oxford University Press, Oxford

Scibek J, Allen DM (2006) Comparing modelled responses of two high-permeability, unconfined aquifers to predicted climate change. Glob Planet Change 50:50-62

Scibek J, Allen DM, Cannon AJ, Whitfield PH (2007) Groundwater-surface water interaction under scenarios of climate change using a high-resolution transient groundwater model. J Hydrol 333:165-181

Serrat-Capdevila A, Valdés JB, Pérez JG, Baird K, Mata LJ, Maddock T (2007) Modeling climate change impacts - and uncertainty - on the hydrology of a riparian system: The San Pedro Basin (Arizona/Sonora). J Hydrol 347:48-66

Shah T (2009) Climate change and roundwater: India's opportunities for mitigation and adaptation. Environ Res Lett 4:035005

Shah T, Burke J, Villholth K et al (2007) Groundwater: a global assessment of scale and significance Water for Food, Water for Life: a comprehensive assessment of water management in agriculture. IWMI, Colombo, Sri Lanke, pp 395-423

Shiklomanov IA (ed) (1997) Comprehensive assessment of the freshwater resources of the world: assessment of water resources and water availability in the world. World Meteorological Organization, Geneva

SMAAR (Syrian Ministry of Agriculture and Agrarian Reform) (1999) The annual agricultural statistical abstract 1996. Department of Planning and Statistics, Division of Agricultural Statistics Computer Center, Damascus

Stigter TY, Carvalho Dill AMM, Ribeiro L, Reis E (2006) Impact of the shift from groundwater to surface water irrigation on aquifer 
dynamics and hydrochemistry in a semi-arid region in the south of Portugal. Agric Water Manage 85:121-132

Thomas A (2008) Agricultural irrigation demand under present and future climate scenarios in China. Glob Planet Change 60:306-326

Timmermann A, Oberhuber J, Bacher A, Esch M, Latif M, Roeckner E (1999) Increased El Niño frequency in a climate model forced by future greenhouse warming. Nature 398:694-697

Tubiello FN, Donatelli M, Rosenzweig C, Stockle CO (2000) Effects of climate change and elevated $\mathrm{CO} 2$ on cropping systems: model predictions at two Italian locations. Eur J Agron 13(2-3):179-189

Tuong TP, Bouman BAM, Mortimer M (2005) More rice, less water: integrated approaches for increasing water productivity in irrigated rice based systems in Asia. Plant Prod Sci 8(3):231-241

Turral H, Svendsen M, Faures JM (2009) Investing in irrigation: reviewing the past and looking to the future. Agric Water Manage 97(4):551-560. doi:10.1016/j.agwat.2009.07.012

UNESCO (United Nations Educational Scientific and Cultural Organization) (2008) Groundwater resources assessment under the pressures of humanity and climate change (GRAPHIC) http://www.unesco.org/water/ihp/graphic/ . Cited 19 May 2010
USDA (2008) The Effects of climate change on agriculture, land resources, water resources, and biodiversity in the United States. U.S. Climate Change Science Program Synthesis and Assessment Product 4.3. USDA, Washington, DC. http://www.climatescience. gov. Cited March 2010

Van Hofwegen P, Svendsen M (2000) A vision of water for food and rural development. World Water Forum, The Hague

Wakil M (1993) Analysis of future water-needs of different sectors in Syria. Water Int 18:18-22

Wilson SG, Hunt BG (1997) Impact of greenhouse warming on El Niño/Southern Oscillation behaviour in a high resolution coupled global climatic model. Report to Environment Australia. CSIRO Division of Atmospheric Research, Melbourne, Australia

Yang YH, Watanabe M, Tang CY, Sakura Y, Hayashi S (2002) Groundwater table and recharge changes in the piedmont region of Taihang Mountain in Gaocheng City and its relation to agricultural water use. Water SA 28:171-178

Yang YH, Watanabe M, Zhang XY, Zhang JQ, Wang QX, Hayashi S (2006) Optimizing irrigation management for wheat to reduce groundwater depletion in the piedmont region of the Taihang Mountains in the North China Plain. Agric Water Manage 82:25-44 